\title{
MANUFACTURING STRATEGIES AND CHOICES IN CULTURAL CONTEXTS1
}

\author{
Ruth Alas $^{1}$, Ants Kraus ${ }^{2}$, Katrin Niglas ${ }^{3}$ \\ ${ }^{1,2}$ Estonian Business School, Lauteri 3, 10114 Tallinn, Estonia \\ ${ }^{3}$ University of Tallinn, Narva mnt 25, 10120 Tallinn, Estonia

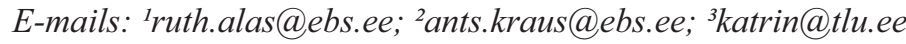

Received 16 February 2008; accepted 2 July 2009

\begin{abstract}
Although any firm operates in a local environment, which includes specific economic, social and cultural contexts, there is still a lack of studies connecting culture and values with operations strategies and practices. This paper attempts to explore a look at how cultural dimensions are connected with manufacturing strategies and choices. The current article is based on data from the International Manufacturing Strategy Survey (IMSS) project and the GLOBE study. Advanced mass production is more common to countries with high assertiveness, power distance and uncertainty avoidance. The model of manufacturing strategies and choices in cultural context is developed based on empirical results of the study.
\end{abstract}

Keywords: manufacturing, culture, IMSS survey, GLOBE study, assertiveness, uncertainty avoidance, power distance.

\section{Introduction}

Majority of manufacturing management literature has been content-related (Dangayach, Deshmukh 2001). At the same time in the framework developed for evaluation of manufacturing strategy process Mills et al. (1995) suggest to consider also the fact that external context and research in multinational corporations has indicated, that organizational processes in manufacturing are influenced by national institutional features (Geppert, Matten 2006). The need to consider cultural factors in strategic issues has been emphasized (Wilkinson et al. 2008). Galan and Sanchez-Bueno (2009) point out the importance of context factors as highly important in firm's choice of strategy.

Although any firm operates in a local environment which includes specific economic, social and cultural contexts (Moattar-Husseini, O'Brien 2004) and there has been significant body of operations management research (Frohlich 2002; Rungtusanatham et al. 2003) there is still a lack of studies connecting culture and

${ }^{1}$ Research was supported by ETF grant 7537 values with operations strategies and practices. The paper tries to explore how cultural dimensions are connected with manufacturing choices and patterns of responses.

The use of field-based empirical methodologies in the production and operations management (POM) area has been steadily increasing over the past decade. One of the most prominent among these is the survey research methodology which has often been used to capture data from business organizations (Malhotra, Grover 1998).

The article is based on data from the fourth International Manufacturing Strategy Survey (IMSS) project and GLOBE study. Paper starts with theoretical framework for these studies. Which is followed by the results of an empirical analysis and the model of manufacturing strategies and choices in cultural context.

\section{The research framework}

According to comprehensive assessment of 285 survey research articles in operations management since the second half of the 1990s, two topics stood out as 
showing fastest ascendancy to prominence - operations strategy and supply chain management (Rungtusanatham et al. 2003). Swamidass and Newell (1987) were among the first researchers who focused on connections between environment and manufacturing strategy. Prochno and Correa (1995) connected manufacturing strategy with political and economic situation.

One of the most contributing surveys for studying manufacturing strategies on a global scale and at the national level is the International Manufacturing Strategy Survey (IMSS) (Cagliano et al. 2008; MoattarHusseini, O'Brien 2004). First round of this survey was in 1993 (Lindberg et al. 1998). The research method is a questionnaire survey, performed by an international network of researchers in various countries. After data collection, a database from the entire worldwide study will be distributed to all contributing researchers and participating companies.

The framework of the study is based on a manufacturing strategy perspective (Alas et al. 2009). This means that emphasis is placed on understanding the strategies and market priorities of the business units, the strategy's translation into manufacturing objectives, the manufacturing practices, and the areas of current and future manufacturing improvement activities (Cagliano et al. 2008; Caniato et al. 2009). The questionnaire is divided into the following sections:

A. Description, strategy and performance of the business unit. This section explores strategies, markets, primary modes of competition and cost structure data of the business unit.

B. Description, strategy and performance of the dominant activities of the plant. This section explores the manufacturing strategy, process design and manufacturing performance of the dominant activity.

C. Current manufacturing and supply chain practices, and past and planned improvement programmes. This section explores the structure (facilities, technology, and degree of integration) and infrastructure (organization, planning and control systems, quality, and product development) and focuses on use and results from broad areas of activity, action programs, and improvements, such as IT, automation, quality, empowerment, etc.

The goal of the questionnaire development was to provide the tool for finding connection of different manufacturing choices with macro-economic and socio-cultural contexts. Current paper is focusing only on manufacturing strategies and choices in different cultural contexts.

\section{Cultural context}

Culture represents the culmination of a range of historical experiences that have shaped an existing pattern (Forbes, Wield 2002). The deepest level of culture is values (McEwan 2001). Values are active standards that define social and professional behavior (Rassin 2008). Today most organizations are focused on economic values, ethical and emotional values are underestimated (Raich, Dolan 2008).

There is no universally agreed-upon definition among social scientists for the term culture. For the GLOBE Project, which has been considered as one of the most comprehensive studies on national cultures, culture is defined as the shared motives, values, beliefs, identities, and interpretations or meanings of significant events that result from common experiences of members of collectives that are transmitted across generations (House, Javidan 2004). The most parsimonious operationalizations of societal culture consist of commonly experienced language, ideological belief systems (including religion and political belief systems), ethnic heritage and history.

Culture matters because it is a powerful, latent, and often unconscious set of forces that determine both our individual and collective behaviour, perception, thought patterns and values. Globalization opens up many opportunities for business, but it also creates many challenges. One of the most important challenges is acknowledging and appreciating cultural values, practices, and subtleties in different parts of the world. All experts in international business agree that to succeed in global business, managers need the flexibility to respond positively and effectively to practices and values that may be drastically different from what they are accustomed to (House et al. 2004).

The GLOBE Project has studied diverse dimensions of societal and organizational cultures. To address this issue, 735 questionnaire items have been developed on the basis of prior literature and the theories of the GLOBE Project. Responses to these questions by middle managers in two pilot studies were analyzed by conventional psychometric procedures. These analyses resulted in the identification of nine major attributes of culture (House, Javidan 2004):

- Uncertainty Avoidance is the extent to which members of an organization or society strive to avoid uncertainty by relying on established social norms, rituals, and bureaucratic practices. People in high uncertainty avoidance cultures actively seek to decrease the probability of unpredictable future events that could adversely affect the operation of 
an organization or society and remedy the success of such adverse effects.

- Power Distance is the degree to which members of an organization or society expect and agree that power should be stratified and concentrated at higher levels of an organization or government.

- Institutional Collectivism, or Collectivism I, is the degree to which organizational and societal institutional practices encourage and reward collective distribution of resources and collective action.

- In-Group Collectivism, or Collectivism II, is the degree to which individuals express pride, loyalty and cohesiveness in their organizations or families.

- Gender Egalitarianism is the degree to which an organization or a society minimizes gender role differences while promoting gender equality.

- Assertiveness is the degree to which individuals in organizations or societies are assertive, confrontational and aggressive in social relationships.

- Future Orientation is the degree to which individuals in organizations or societies engage in futureoriented behaviours such as planning, investing in the future and delaying individual or collective gratification.

- Performance Orientation is the degree to which an organization or society encourages and rewards group members for performance improvement and excellence.

- Humane Orientation is the degree to which an organization or society encourages and rewards individuals for being fair, altruistic, generous, caring and kind to others.

In order to examine manufacturing choices and responses in different cultural contexts, data from two international surveys - International Manufacturing Strategy Survey (IMSS) and Globe study - were combined.

\section{Empirical studies}

\subsection{Methodology}

Fourth International Manufacturing Strategy Survey (IMSS) was designed to explore and identify strategies, practices and performance of manufacturing firms around the world during 2005. The survey included 711 companies in 23 countries: Argentina, Brazil and Venezuela from South America; Canada and USA from North America; Belgium, Denmark, Estonia, Germany, Greece, Hungary, Ireland, Italy, Norway, Portugal, Sweden, The Netherlands and United Kingdom from Europe; China, Israel and Turkey from Asia; also Australia and New Zealand.
Independent country-based research teams performed surveys in each country. The overall coordinator of the project is Politecnico di Milano.

The primary method for data gathering was a questionnaire, which was distributed to the major business units in the ISIC 28-35 industrial sector within each country. The questionnaire was translated from English into local languages and retranslated to English in order to be sure, that translation is accurate. The questionnaire was filled in by operations, manufacturing or technical managers of the companies.

The data about cultural dimensions listed in Appendix 1 is taken from the Globe study (House et al. 2004; Alas 2006, Papalexandris 2006). Cultural practices were measured using the responses of middle managers to questionnaire items concerning "What Is", or "What Are", common behaviours, institutional practices, proscriptions, and prescriptions. A 7-point scale was used, where ' 1 ' indicated 'strongly disagree' and ' 7 ' 'strongly agree'.

The authors of the current paper conducted both studies in one country: Estonia.

In order to group variables, principal component analysis and exploratory factor analysis with varimax rotation was completed. For grouping countries hierarchical as well as k-means cluster analysis was undertaken.

\subsection{Subscales for manufacturing strategies}

In order to reduce number of variables and get more reliable indicators, principal component analysis followed by the exploratory factor analysis with varimax rotation was completed for the variables describing different aspects of manufacturing strategies and operations. Some of the original variables were excluded from the analysis due to the bad fit with the resulting factor model. In the final model 3 factors explain $66.6 \%$ of the total variance of 31 initial variables (see Appendix 2). The subscales for each factor were computed by the aid of the regression algorithm built into the factor analysis tool in the SPSS software. The internal reliability of our three subscales was confirmed by theoretical fit and also by the fact that the factor loadings of every initial variable were very high for one factor and relatively high proportion of the initial variance is described by the model.

The first factor, where the following item has the highest factor loading: coordinating planning decisions and flow of goods takes place by collaborative planning, forecasting and replenishment with key/strategic customers, can be called Advanced Mass Production (F1-AMP). Companies ranking highly in this factor 
manage or hold inventories of materials at customers' site(s) and may even have physical integration with the partner. Such methods as Management Product LifeCycle and Project Management by using of Enterprise Resource Planning (ERP) systems are also important. Job rotation between design and manufacturing takes place. Improvement goals for manufacturing function for the next 3 years are planned to improve companies' environmental performance and employee satisfaction. Also, over the past three years programs for quality improvement and control (e.g. TQM programs, $6 \sigma$ projects, quality circles, etc.) have been undertaken. Mass production is dominating.

The second factor could be called Enterprise Resource Planning (F2-ERP). The companies ranking highly in this factor are becoming more contemporary through the use of Enterprise Resource Planning systems for supporting the most of core management areas: Purchasing and supply management, Material management, Production planning and control, Material management, Production planning and control, Accounting and finance, Distribution management and Sales management. Action program undertaken over the past three years is Rethinking and restructuring supply strategy and the organization and management of suppliers portfolio through e.g. tiered networks, bundled outsourcing, and supply base reduction. Implementing Continuous Improvement Programs through systematic initiatives (e.g. kaizen, improvement teams, etc.) had been planned for the coming three years.

The third factor can be called the Most Fluctuating Demand (F3-MFD). The companies ranking highly in this factor value trustful relationship with customers achieved by delivering in time although demand is fluctuating. In order to be able to do this, they share inventory level knowledge with key/strategic customers. In the cost structure the proportion of direct materials/parts/components is relatively high. Improvement goals for manufacturing function for the next 3 years are connected with increasing volume of flexibility and labour productivity, and with reducing procurement costs.

Values of factor variables for each country are given in Table 1. Also number of companies participating in survey from each country could be found in Table 1 . For the first factor China and Brazil have the highest values. Next are Israel and Turkey. Lowest are Germany and Sweden. In the second factor Sweden and Brazil are the highest, lowest are New Zealand and Canada. In the third factor highest values are for Venezuela and Turkey, lowest for Australia and Israel.
Table 1. Values of 3 manufacturing factors in different countries

\begin{tabular}{|c|c|c|c|c|}
\hline Country & $\mathrm{N}$ & F1 & $\mathrm{F} 2$ & F3 \\
\hline Argentina & 44 & 0.202 & -0.311 & 0.304 \\
\hline Australia & 14 & -0.094 & -1.187 & -2.376 \\
\hline Belgium & 32 & -0.401 & 0.601 & -0.551 \\
\hline Brazil & 16 & 2.027 & 0.986 & 0.327 \\
\hline Canada & 25 & -0.065 & -1.727 & -1.088 \\
\hline China & 38 & 2.356 & 0.152 & -0.736 \\
\hline Denmark & 36 & -0.432 & 0.793 & -0.692 \\
\hline Estonia & 21 & $0, .638$ & -0.892 & 0.427 \\
\hline Germany & 18 & -1.334 & 0.954 & 0.945 \\
\hline Greece & 13 & 0.257 & 0.117 & -0.703 \\
\hline Hungary & 54 & -0.477 & -1.508 & 1.479 \\
\hline Ireland & 15 & -0.943 & -0.059 & 0.217 \\
\hline Israel & 20 & 1.638 & 0.156 & -1.892 \\
\hline Italy & 45 & -0.471 & 0.065 & 0.033 \\
\hline New Zealand & 30 & -0.768 & -2.247 & -0.280 \\
\hline Norway & 17 & -0.728 & -0.803 & 0.773 \\
\hline Portugal & 10 & 0.514 & -0.604 & 0.306 \\
\hline Sweden & 82 & -1.056 & 1.417 & 0.527 \\
\hline The Netherlands & 63 & -0.672 & 0.647 & -1.343 \\
\hline Turkey & 35 & 1.620 & 0.940 & 1.172 \\
\hline United Kingdom & 17 & -0.587 & -0.923 & -1.626 \\
\hline USA & 36 & 0.458 & 0.003 & 0.591 \\
\hline Venezuela & 30 & 1.070 & -0.223 & 1.589 \\
\hline
\end{tabular}

Notes: Bold marks highest values, italic - lowest values.

F1 - Advanced Mass Production ( F1-AMP)

F2 - Enterprise Resource Planning systems users (F2-ERP)

F3 - Most Fluctuating Demand (F3-MFD)

\subsection{Connections between Manufacturing and Culture}

The results of the correlation analysis in Tables 2 and 3 indicate how cultural practices and values are connected with three factors of manufacturing. These connections are taken as the bases for developing model of manufacturing strategies and choices in cultural context.

\subsection{Clusters of countries}

Hierarchical cluster analysis using Average Linkage Between Groups indicated 5 clusters of countries. First cluster consists of Belgium, Denmark, The Netherlands, Greece, Ireland, Italy, Germany and Sweden. Second is formed by Hungary, Norway, Estonia, Portugal, Argentina, USA and Venezuela. Australia, United 
Table 2. Correlations between Manufacturing and cultural practices

\begin{tabular}{lccc}
\hline & $\mathrm{F} 1$ & $\mathrm{~F} 2$ & $\mathrm{~F} 3$ \\
\hline Assertiveness & $.138(* *)$ & $-.227(* *)$ & $.095(*)$ \\
\hline $\begin{array}{l}\text { Institutional } \\
\text { collectivism }\end{array}$ & $-.297(* *)$ & $.410(* *)$ & $-.324(* *)$ \\
\hline $\begin{array}{l}\text { Group } \\
\text { Collectivism }\end{array}$ & $.694(* *)$ & $-.228(* *)$ & $.356\left(^{* *}\right)$ \\
\hline $\begin{array}{l}\text { Future } \\
\text { Orientation }\end{array}$ & $-.332(* *)$ & $.473(* *)$ & $-.442(* *)$ \\
\hline $\begin{array}{l}\text { Gender } \\
\text { egalitarianism }\end{array}$ & $-.518(* *)$ & -.057 & $.127(* *)$ \\
\hline $\begin{array}{l}\text { Humane } \\
\text { Orientation }\end{array}$ & .048 & $.077(*)$ & $-.374(* *)$ \\
\hline $\begin{array}{l}\text { Performance } \\
\text { Orientation }\end{array}$ & -.026 & $-.131(* *)$ & $-.594(* *)$ \\
\hline Power Distance & $.156(* *)$ & $-.339(* *)$ & $.629(* *)$ \\
\hline $\begin{array}{l}\text { Uncertainty } \\
\text { Avoidance }\end{array}$ & $-.412(* *)$ & $.448(* *)$ & $-.401(* *)$ \\
\hline
\end{tabular}

Notes: ** Correlation is significant at the 0.01 level (2-tailed).

* Correlation is significant at the 0.05 level (2-tailed).

F1 - Advanced Mass Production ( F1-AMP)

F2 - Enterprise Resource Planning systems users (F2-ERP).

F3 - Most Fluctuating Demand (F3-MFD)

Table 3. Connections between Manufacturing and cultural practices

\begin{tabular}{|c|c|c|c|}
\hline & $\begin{array}{c}\text { Advanced } \\
\text { Mass } \\
\text { Production }\end{array}$ & $\begin{array}{c}\text { Enterprise } \\
\text { Resource } \\
\text { Planning } \\
\text { systems } \\
\text { users }\end{array}$ & $\begin{array}{c}\text { Most } \\
\text { Fluctuating } \\
\text { Demand }\end{array}$ \\
\hline Assertiveness & + & - & + \\
\hline $\begin{array}{l}\text { Group } \\
\text { Collectivism }\end{array}$ & + & - & + \\
\hline $\begin{array}{l}\text { Power } \\
\text { Distance }\end{array}$ & + & - & + \\
\hline $\begin{array}{l}\text { Institutional } \\
\text { Collectivism }\end{array}$ & - & + & - \\
\hline $\begin{array}{l}\text { Future } \\
\text { Orientation }\end{array}$ & - & + & - \\
\hline $\begin{array}{l}\text { Uncertainty } \\
\text { Avoidance }\end{array}$ & - & + & - \\
\hline $\begin{array}{l}\text { Gender } \\
\text { Egalitarianism }\end{array}$ & - & & + \\
\hline $\begin{array}{l}\text { Humane } \\
\text { Orientation }\end{array}$ & & + & - \\
\hline $\begin{array}{l}\text { Performance } \\
\text { Orientation }\end{array}$ & & - & - \\
\hline
\end{tabular}

Kingdom, Canada and New Zealand form the third cluster. The fourth cluster includes Brazil and Turkey, and the fifth - China and Israel.

Table 4 lists the cluster centers which are the mean values of every cluster for underlying three factor variables. The first cluster could be called traditional Europe. This cluster has the lowest value for the first factor and average values for the second and third factors. This cluster compared to other clusters has the highest values for Future orientation and Uncertainty avoidance.

Table 4. Final Cluster Centers and means for Cultural variables

\begin{tabular}{lccccc}
\hline \multicolumn{5}{c}{ Clusters } \\
\hline & 1 & 2 & 3 & 4 & 5 \\
& $\mathrm{~N}=8$ & $\mathrm{~N}=7$ & $\mathrm{~N}=4$ & $\mathrm{~N}=2$ & $\mathrm{~N}=2$ \\
\hline F1-AMP & -0.63 & 0.24 & -0.38 & 1.82 & $\mathbf{2 . 0 0}$ \\
\hline F2-ERP & 0.57 & -0.62 & -1.52 & $\mathbf{0 . 9 6}$ & 0.15 \\
\hline F3-MFD & -0.20 & $\mathbf{0 . 7 8}$ & -1.34 & 0.75 & -1.31 \\
\hline Cultural & & & & & \\
practices & & & & & \\
\hline Assertiveness & 4.17 & 4.24 & 4.04 & $\mathbf{4 . 3 4}$ & 3.98 \\
\hline $\begin{array}{l}\text { Institutional } \\
\text { collectivism }\end{array}$ & 4.36 & 3.87 & 4.49 & 3.98 & $\mathbf{4 . 5 4}$ \\
\hline $\begin{array}{l}\text { Group } \\
\text { Collectivism }\end{array}$ & 4.35 & 5.15 & 4.01 & $\mathbf{5 . 4 8}$ & 5.25 \\
\hline $\begin{array}{l}\text { Future } \\
\text { Orientation }\end{array}$ & $\mathbf{4 . 1 3}$ & 3.66 & 4.07 & 3.82 & 3.75 \\
\hline $\begin{array}{l}\text { Gender } \\
\text { egalitarianism }\end{array}$ & 3.52 & $\mathbf{3 . 6 2}$ & 3.48 & 3.23 & 3.12 \\
\hline $\begin{array}{l}\text { Humane } \\
\text { Orientation }\end{array}$ & 4.02 & 3.84 & $\mathbf{4 . 2 5}$ & 3.84 & 4.18 \\
\hline $\begin{array}{l}\text { Performance } \\
\text { Orientation }\end{array}$ & 4.04 & 3.75 & $\mathbf{4 . 4 6}$ & 3.97 & 4.20 \\
\hline $\begin{array}{l}\text { Power } \\
\text { Distance }\end{array}$ & 4.97 & 5.32 & 5.01 & $\mathbf{5 . 3 4}$ & 4.87 \\
\hline $\begin{array}{l}\text { Uncertainty } \\
\text { Avoidance }\end{array}$ & $\mathbf{4 . 6 4}$ & 3.76 & 4.63 & 3.71 & 4.39 \\
\hline & & & & & \\
\hline
\end{tabular}

Note: Bold marks highest values, italic - lowest values.

The second cluster is a mixed cluster from peripheral European countries including also USA and two south American countries: Argentina and Venezuela. This cluster has the highest value on the third factor, middle value for the first factor and relatively low value for the second factor. This cluster has the lowest Institutional collectivism, Uncertainty avoidance, Future orientation, Humane orientation and Performance orientation compared to other clusters. At the same time Gender egalitarianism is highest. 
The third cluster consists of Australia and New Zealand, UK and Canada. This cluster has the lowest values in the second and third factors and second lowest in the first factor. Humane orientation and Performance orientation are the highest in this cluster. Group collectivism is lower than in all other clusters.

The fourth cluster includes Brazil and Turkey and has very high values compared to the other clusters by all three factors. Also Assertiveness, Group collectivism and Power distance are highest in this cluster and Humane orientation and Uncertainty avoidance is lowest in this cluster.

The fifth cluster consisting of China and Israel has the highest value for the first factor, but the lowest for the third one. Institutional collectivism is the highest in this cluster. Assertiveness, Power distance and Gender egalitarianism are the lowest compared to other clusters.

\section{Conclusions and discussion}

Although any firm operates in a local environment which includes specific economic, social and cultural contexts (Moattar-Husseini, O'Brien 2004), there have been only few articles exploring manufacturing with soft issues (Fang, Wang 2006). This paper attempts to fill this gap. Based on data from the fourth International Manufacturing Strategy Survey (IMSS) project and GLOBE study, authors explored how cultural dimensions are connected with manufacturing choices and patterns of responses.

Data from International Manufacturing Strategy Survey (IMSS) enabled authors to filter out three dominant manufacturing strategies and choices:

- Advanced Mass Production (F1-AMP),

- Enterprise Resource Planning systems usage (F2-ERP),

- Most Fluctuating Demand (F3-MFD).

Advanced Mass Production means coordinating planning decisions and flow of goods by collaborative planning, forecasting and replenishment with key/ strategic customers. Companies ranking highly in this factor also manage or hold inventories of materials at customers' site(s) and may even have physical integration with the partner. They use most advanced methods of Enterprise Resource Planning (ERP) systems for managing product life-cycle. Job rotation between design and manufacturing gives possibility to develop both functions better by sharing knowledge between employees responsible for these two functions. Improvement goals for manufacturing function for the next 3 years are to improve companies' environmental performance and employee satisfaction. Over the last three years programs for quality improvement and control (e.g. TQM programs, $6 \sigma$ projects, quality circles, etc.) were undertaken.

Enterprise Resource Planning (ERP) systems users are becoming more contemporary through the use of Enterprise Resource Planning systems for supporting the most of core management areas: purchasing and supply management, material management, production planning and control, material management, production planning and control, accounting and finance, distribution management and sales management. Action programs have been undertaken for rethinking and restructuring of supply strategy. Implementing Continuous Improvement Programs through systematic initiatives (e.g. kaizen, improvement teams, etc.) has been planned for the coming three years.

The Most Fluctuating Demand requires trustful relationship with customers achieved by delivering in time although demand is fluctuating. In order to be able to do this, inventory level knowledge is shared with key/ strategic customers. Improvement goals for manufacturing function for the next 3 years are connected with increasing volume flexibility and labour productivity. At the same time procurement costs should be reduced. Cluster analysis grouped countries into 5 clusters according to manufacturing strategies.

Based on IMSS survey in 1993 Moattar-Husseini and O'Brien (2004) compared 4 largest economies in Latin America with such industrially leading countries as USA and Japan and with industrially advanced European countries such as UK, Germany and Italy. They found that as a result of considerable environmental changes during last decades, firms in Latin American countries have had to adopt new strategies and these firms are catching up their competitors in well-established industrial countries. According to current survey this trend has continued as Latin American countries belong to the same group with USA. The results of the survey indicate most advanced production taking place in Brazil.

Current paper indicates connections between manufacturing strategies and cultural orientations from the Globe study.

For example, countries with high first factor values advanced mass production - have low uncertainty avoidance while at the same time there are less established social norms, rituals, and bureaucratic practices in these countries. These countries have also high ingroup collectivism. Members of these societies express 
pride, loyalty, and cohesiveness in their organizations or families.

In countries, where the value for the second factor is high - companies are becoming more contemporary through the use of Enterprise Resource Planning systems for supporting the most of core management areas - Institutional collectivism, Uncertainty avoidance and Future orientation are higher than in other countries.

Countries with high third factor values - the most fluctuating demand - have higher power distance and lower performance orientation. Members of these societies expect and agree that power should be stratified and concentrated at higher levels of an organization or government. Individual group members are not encouraged and rewarded for performance improvement and excellence.

Based on empirical data authors developed the Model of manufacturing strategies and choices in cultural context (Fig. 1).

Based on connections between manufacturing strategies and cultural practices three groups of cultural dimensions could be differentiated.

First group is formed from Assertiveness, Group Collectivism and Power Distance. In the countries with higher Assertiveness, Group Collectivism, Power Distance the manufacturing strategy based on the use of Enterprise Resource Planning systems is more common than in other countries. The advanced mass production is more common in countries with lower Assertiveness, Group Collectivism and Power Distance practices. At the same time fluctuation of demand can also be high.

The second group consists of Institutional collectivism, Future Orientation and Uncertainty Avoidance. Enterprise Resource Planning systems are more often used in the countries with lower Institutional Collectivism, Future Orientation and Uncertainty Avoidance practices. Demand is more fluctuating and there are more plants orientated to advanced mass production in countries with lower Institutional Collectivism, Future Orientation and Uncertainty Avoidance.

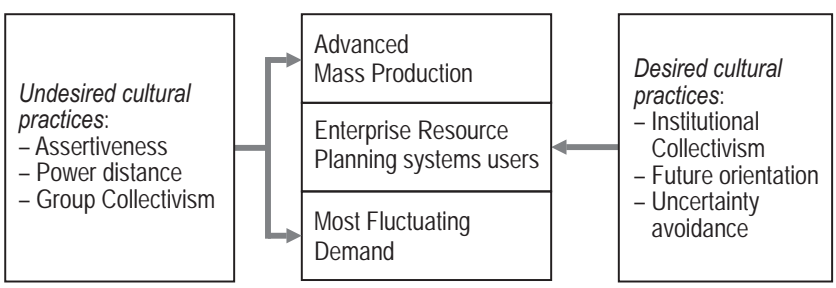

Fig. 1. Model of manufacturing strategies and choices in cultural context
There are statistically less significant connections and no regularity in the third group of cultural dimensions: Gender Egalitarianism, Humane Orientation and Performance Orientation.

Societal cultural practices are divided into desired and undesired practices (Alas 2006). Practices, which form the first group in the current study - high Assertiveness, Power distance and Uncertainty avoidance - are undesired practices. People in these countries want to change these. Second group in the current study is formed from the desired practices like Institutional collectivism, Future orientation, and Uncertainty avoidance. Humane orientation from the third group is also desired practice. In connections with development of human resource management function in organizations these groups of practices have been called enabling and disabling practices (Alas et al. 2008). But according to results of current study authors found the terms 'desired and undesired practices' more suitable.

To summarize the model, advanced mass production and more fluctuating demand are more common to the countries with such undesired cultural practices as high Assertiveness, Power distance and Uncertainty avoidance. Countries with desired cultural practices use Enterprise Resource Planning systems in most of functional areas, although previous research has indicated, that implementing ERP systems has proven unexpectedly difficult (Yen, Sheu 2004). Advanced mass production moves out from countries with desired cultural practices to countries with undesired cultural practices.

To conclude, although there are several factors influencing manufacturing strategy and choices, cultural practices also have the connection with manufacturing. Advanced mass production moves out from countries with desired cultural practices to countries with undesired cultural practices. Therefore, obtaining knowledge about traditions and customs in a concrete country is useful before starting production in this country.

\section{References}

Alas, R. 2006. Ethics in countries with different cultural dimensions, Journal of Business Ethics 69(3): 237-247. doi:10.1007/s10551-006-9088-3

Alas, R.; Kaarelson, T.; Niglas, K. 2008. Human resource management in cultural context: empirical study of 11 countries, EBS Review 24(1): 50-62.

Alas, R.; Eklund, T.; Collan, M.; Kraus, A. 2009. International patterns in manufacturing strategies, in Pablos, P. O. and Lytras, M. D. (Eds.). The China Information Technology Handbook. Springer. Forthcoming. 
Cagliano, R.; Caniato, F.; Golini, R.; Kalchschmidt, M.; Spina, G. 2008. Supply chain configurations in a global environment: A longitudinal perspective, Operations Management Research 1(2): 86-94. doi:10.1007/s12063-008-0012-0

Caniato, F.; Cagliano, R.; Kalchschmidt, M.; Golini, R.; Spina, G. 2009. Evolutionary patterns in e-business strategy, International Journal of Operations \& Production Management 29(9): 921-945. doi:10.1108/01443570910986229

Dangayach, G. S. and Deshmukh, S. G. 2001. Manufacturing strategy: Literature review and some issues, International Journal of Operations \& Production Management 21(7): 884-932. doi:10.1108/01443570110393414

Fang, S.-C. and Wang, J.-F. 2006. Effects of organizational culture and learning on manufacturing strategy selection: an empirical study, International Journal of Management 23(3/1): 503-514.

Forbes, N. and Wield, D. 2002. From followers to leaders: Managing technology and innovation. Routledge.

Frohlich, M. T. 2002. Techniques for improving response rate in OM surveys, Journal of Operations Management 20: 53-62. doi:10.1016/S0272-6963(02)00003-7

Galan, J. I. and Sanchez-Bueno, M. J. 2009. Strategy and structure in context: Universalism versus institutional effects, Organization Studies 30(6): 609-627. doi:10.1177/0170840609104802

Geppert, M. and Matten, D. 2006. Institutional Influences on manufacturing organization in multinational corporations: The 'Cherrypicking' approach, Organization Studies 27(4): 491-515. doi:10.1177/0170840605059452

House, R. J.; Hanges, P. J.; Javidan, M.; Dorfman, P. W.; Gupta, V. 2004. Culture, Leadership, and Organizations. The GLOBE Study of 62 Societies. Sage Publications, Inc.

House, R. J. and Javidan, M. 2004. Overview of globe, in House, R. J.; Hanges, P. J.; Javidan, M.; Dorfman, P. W.; Gupta, V. (Eds.). Culture, Leadership, and Organizations. The GLOBE Study of 62 Societies. Sage Publications, Inc., 9-48.

Lindberg, P.; Voss, C. A.; Blackmon, K. 1998. International manufacturing strategies: Context, content and change. Kluwer Academic Publishers, Dordrecht.

Malhotra, M. K. and Grover, V. 1998. An assessment of survey research in POM: from constructs to theory, Journal of Operations Management 16: 407-425.

doi:10.1016/S0272-6963(98)00021-7
McEwan, T. 2001. Managing values and beliefs in organizations. Prentice Hall.

Mills, J.; Platts, K.; Gregory, M. 1995. A framework for the design of manufacturing strategy process: a contingency approach, International Journal of Operations \& Production Management 15(4): 17-40.

doi: $10.1108 / 01443579510083596$

Moattar-Husseini, S. M.; O’Brien, C. O. 2004. Strategic implications of manufacturing performance comparisons for newly industrializing countries, International Journal of Operations \& Production Management 24(11/12): 11261148. doi:10.1108/01443570410563269

Papalexandris, N. 2006. Greece, from ancient myths to modern realities, in Chhokar, J. S.; Brodbeck, F. C.; House, R. J. (Eds.). Global Leadership and Organizational Behavior Effectiveness. Lawrence Erlbaum Associates, Mahwah, NJ.

Prochno, P. J. L. C. and Correa, H. L. 1995. The development of manufacturing strategy in a turbulent environment, International Journal of Operations \& Production Management 15(11): 20-36. doi:10.1108/01443579510102873

Raich, M.; Dolan, S. L. 2008. Beyond: business and society in transformation. Basingstoke: Palgrave Macmillan.

Rassin, M. 2008. Nurses' Professional and Personal Values, Nursing Ethics 15(5): 614-630.

doi:10.1177/0969733008092870

Rungtusanatham, M. J.; Choi, T. Y.; Hollingworth, D. G.; Wu, Z.; Forza, C. 2003. Survey research in operations management: historical analyses, Journal of Operations Management 21: 475-488. doi:10.1016/S0272-6963(03)00020-2

Swamidass, P. M. and Newell, W. T. 1987. Manufacturing strategy, environmental uncertainty and performance: A path analytic model, Management Science 33(4): 509-524. doi: $10.1287 / \mathrm{mnsc} .33 .4 .509$

Wilkinson, T. J.; Peng, G. Z.; Brouthers, L. E.; Beamins, P. W. 2008. The diminishing effect of cultural distance on subsidiary control, Journal of International Management 14(2): 93-107. doi:10.1016/j.intman.2007.08.003

Yen, R. H. and Sheu, C. 2004. Aligning ERP implementation with competitive priorities of manufacturing firms: An exploratory study, International Journal of Production Economics 92(3): 207-220. doi:10.1016/j.ijpe.2003.08.014 


\section{APPENDIX 1}

Cultural practices

\begin{tabular}{|c|c|c|c|c|c|c|c|c|c|}
\hline Country & 1 & 2 & 3 & 4 & 5 & 6 & 7 & 8 & 9 \\
\hline United Kingdom & 4.23 & 4.31 & 4.08 & 4.31 & 3.67 & 3.74 & 4.16 & 5.26 & 4.70 \\
\hline Germany & 4.66 & 3.97 & 4.16 & 4.41 & 3.25 & 3.30 & 4.42 & 5.48 & 5.35 \\
\hline Sweden & 3.41 & 5.26 & 3.46 & 4.37 & 3.72 & 4.09 & 3.67 & 4.94 & 5.36 \\
\hline Denmark & 4.04 & 4.93 & 3.63 & 4.59 & 4.02 & 4.67 & 4.40 & 4.14 & 5.32 \\
\hline The Netherlands & 4.46 & 4.62 & 3.79 & 4.72 & 3.62 & 4.02 & 4.46 & 4.32 & 4.81 \\
\hline Italy & 4.12 & 3.75 & 4.99 & 3.34 & 3.30 & 3.66 & 3.66 & 5.45 & 3.85 \\
\hline \multicolumn{10}{|l|}{ Norway } \\
\hline Turkey & 4.42 & 4.02 & 5.79 & 3.74 & 3.02 & 3.92 & 3.82 & 5.43 & 3.67 \\
\hline Ireland & 3.93 & 4.57 & 5.12 & 3.93 & 3.19 & 4.96 & 4.30 & 5.13 & 4.25 \\
\hline Greece & 4.55 & 3.41 & 5.28 & 3.53 & 3.53 & 3.44 & 3.34 & 5.35 & 3.52 \\
\hline \multicolumn{10}{|l|}{ Belgium } \\
\hline Hungary & 4.71 & 3.63 & 5.31 & 3.31 & 4.02 & 3.39 & 3.50 & 5.57 & 3.26 \\
\hline Australia & 4.29 & 4.31 & 4.14 & 4.09 & 3.41 & 4.32 & 4.37 & 4.81 & 4.40 \\
\hline New Zealand & 3.53 & 4.96 & 3.58 & 3.46 & 3.18 & 4.43 & 4.86 & 5.12 & 4.86 \\
\hline Israel & 4.19 & 4.40 & 4.63 & 3.82 & 3.21 & 4.07 & 4.03 & 4.71 & 3.97 \\
\hline USA & 4.50 & 4.21 & 4.22 & 4.13 & 3.36 & 4.18 & 4.45 & 4.92 & 4.15 \\
\hline Canada & 4.09 & 4.36 & 4.22 & 4.40 & 3.66 & 4.51 & 4.46 & 4.85 & 4.54 \\
\hline Estonia & 4.04 & 3.71 & 4.79 & 4.20 & 3.60 & 3.39 & 3.87 & 5.16 & 4.01 \\
\hline Argentina & 4.18 & 3.66 & 5.51 & 3.10 & 3.44 & 3.94 & 3.63 & 5.56 & 3.63 \\
\hline Brazil & 4.25 & 3.94 & 5.16 & 3.90 & 3.44 & 3.76 & 4.11 & 5.24 & 3.74 \\
\hline China & 3.77 & 4.67 & 5.86 & 3.68 & 3.03 & 4.29 & 4.37 & 5.02 & 4.81 \\
\hline Portugal & 3.75 & 4.02 & 5.64 & 3.77 & 3.69 & 3.96 & 3.65 & 5.50 & 3.96 \\
\hline Venezuela & 4.26 & 3.96 & 5.41 & 3.43 & 3.60 & 4.19 & 3.41 & 5.22 & 3.55 \\
\hline
\end{tabular}

Notes:

1 - Assertiveness

2 - Institutional collectivism

3 - Group Collectivism

4 - Future Orientation

5 - Gender egalitarianism

6 - Humane Orientation

7 - Performance Orientation

8 - Power Distance

9 - Uncertainty Avoidance 


\section{APPENDIX 2}

Factors of manufacturing strategies

\begin{tabular}{|c|c|c|c|}
\hline & \multicolumn{3}{|c|}{ Factor } \\
\hline & $\begin{array}{c}1 \\
\text { variance } \\
\text { explained: } \\
27 \%\end{array}$ & $\begin{array}{c}2 \\
\text { variance } \\
\text { explained: } \\
25 \%\end{array}$ & $\begin{array}{c}3 \\
\text { variance } \\
\text { explained: } \\
14 \%\end{array}$ \\
\hline & 1 & 2 & 3 \\
\hline $\begin{array}{l}\text { Coordinate planning decisions and flow of goods with key/strategic customers: } \\
\text { Collaborative Planning, Forecasting and Replenishment }\end{array}$ & .889 & & \\
\hline $\begin{array}{l}\text { Management areas supported through the use of Enterprise Resource Planning } \\
\text { (ERP) systems : Product Life-Cycle Management }\end{array}$ & .852 & .264 & \\
\hline $\begin{array}{l}\text { Coordinate design and manufacturing: Job rotation between design and } \\
\text { manufacturing }\end{array}$ & .849 & & \\
\hline $\begin{array}{l}\text { Operational activity in plant performed using the following technologies: } \\
\text { Automated guided vehicles (AGVs) }\end{array}$ & .845 & .204 & \\
\hline $\begin{array}{l}\text { Management areas supported through the use of Enterprise Resource Planning } \\
\text { systems: Project Management }\end{array}$ & .817 & & \\
\hline $\begin{array}{l}\text { Action programmes planned efforts for the coming three years: Increasing the } \\
\text { technological integration between product development and manufacturing } \\
\text { through e.g. CAD-CAM }\end{array}$ & .807 & & \\
\hline $\begin{array}{l}\text { Improvement goals for your manufacturing function for the next } 3 \text { years: } \\
\text { Improving your environmental performance }\end{array}$ & .779 & & .398 \\
\hline $\begin{array}{l}\text { Coordinate planning decisions and flow of goods with your key/strategic } \\
\text { customers : You manage or hold inventories of materials at your customers' } \\
\text { site(s) (e.g. Vendor Managed Inventory, Consignment Stock) }\end{array}$ & .769 & & \\
\hline Process types (percentage of total volume): Mass production & .742 & .419 & \\
\hline $\begin{array}{l}\text { Coordinate planning decisions and flow of goods with key/strategic customers: } \\
\text { Share production planning decisions and demand forecast knowledge }\end{array}$ & .699 & -.220 & .494 \\
\hline $\begin{array}{l}\text { Coordinate planning decisions and flow of goods with your key/strategic } \\
\text { customers : Physical integration with the partner (e.g. cross-docking, co-location) }\end{array}$ & .683 & -.286 & .403 \\
\hline $\begin{array}{l}\text { Improvement goals for your manufacturing function for the next } 3 \text { years: } \\
\text { Improving employee satisfaction }\end{array}$ & .679 & & .418 \\
\hline $\begin{array}{l}\text { Degree of the action programs undertaken over the last three years: Undertaking } \\
\text { programs for quality improvement and control (e.g. TQM programs, } 6 \sigma \text { projects, } \\
\text { quality circles, etc.) }\end{array}$ & .636 & .256 & \\
\hline $\begin{array}{l}\text { Management areas supported through the use of Enterprise Resource Planning } \\
\text { systems: Purchasing and supply management }\end{array}$ & & .949 & \\
\hline $\begin{array}{l}\text { Management areas supported through the use of Enterprise Resource Planning } \\
\text { systems: Material management }\end{array}$ & & .929 & \\
\hline $\begin{array}{l}\text { Management areas supported through the use of Enterprise Resource Planning } \\
\text { systems: Production planning and control }\end{array}$ & & .853 & \\
\hline $\begin{array}{l}\text { Management areas supported through the use of Enterprise Resource Planning } \\
\text { systems: Accounting and finance }\end{array}$ & & .847 & .262 \\
\hline $\begin{array}{l}\text { Management areas supported through the use of Enterprise Resource Planning } \\
\text { systems: Distribution management }\end{array}$ & & .791 & .211 \\
\hline $\begin{array}{l}\text { Operational activity in your plant performed using the following technologies : } \\
\text { Automated parts loading/unloading }\end{array}$ & .223 & .780 & .215 \\
\hline
\end{tabular}


End of Appendix 2

\begin{tabular}{|c|c|c|c|}
\hline & 1 & 2 & 3 \\
\hline $\begin{array}{l}\text { Degree of the action programs planned efforts for the coming three years: } \\
\text { Implementing Continuous Improvement Programs through systematic initiatives } \\
\text { (e.g. kaizen, improvement teams, etc.) }\end{array}$ & & .759 & \\
\hline $\begin{array}{l}\text { Management areas supported through the use of Enterprise Resource Planning } \\
\text { systems: Sales management }\end{array}$ & .271 & .725 & \\
\hline $\begin{array}{l}\text { Action programs undertaken over the last three years: Rethinking and } \\
\text { restructuring supply strategy and the organization and management of suppliers } \\
\text { portfolio through e.g. tiered networks, bundled outsourcing, and supply base } \\
\text { reduction. }\end{array}$ & & .709 & \\
\hline Coordinate design and manufacturing: Formal meetings & & .606 & .244 \\
\hline $\begin{array}{l}\text { Action programs undertaken over the last three years: } \\
\text { Restructuring manufacturing processes and layout to obtain process focus and } \\
\text { streamlining (e.g. reorganize plant-within -a-plant; cellular layout, etc.) }\end{array}$ & .215 & .496 & -.249 \\
\hline To win orders from your major customers: more dependable deliveries & & & .853 \\
\hline $\begin{array}{l}\text { Improvement goals for your manufacturing function for the next } 3 \text { years: } \\
\text { Increasing labor productivity }\end{array}$ & .326 & & .792 \\
\hline $\begin{array}{l}\text { Improvement goals for your manufacturing function for the next } 3 \text { years: } \\
\text { Reducing procurement costs }\end{array}$ & .220 & & .787 \\
\hline $\begin{array}{l}\text { Coordinate planning decisions and flow of goods with your key/strategic } \\
\text { customers: Share inventory level knowledge }\end{array}$ & .386 & .305 & .619 \\
\hline Cost structure: Direct materials/parts/components & & .324 & .562 \\
\hline $\begin{array}{l}\text { Improvement goals for your manufacturing function for the next } 3 \text { years: } \\
\text { Increasing volume flexibility }\end{array}$ & & .494 & .535 \\
\hline Variation of market demand over a year: demand for lowest month & -.302 & .240 & .517 \\
\hline
\end{tabular}

Extraction Method: Principal Component Analysis.

Rotation Method: Varimax with Kaiser Normalization.

a Rotation converged in 5 iterations.

Factor loadings below 0.2 are not shown. 